\title{
Financial Risk Assessment in Healthcare Organizations
}

\author{
Sağl1k İşletmelerinde Finansal Risklerin Değerlendirmesi
}

\author{
Murat TÜRK ${ }^{1}$ \\ (D) 0000-0002-7415-8965 \\ İlhan EROĞLU ${ }^{2}$ \\ (D) 0000-0003-4711-1165
}

\begin{abstract}
Aim: Risk assessment is one of the important processes of risk management. This study aims to show how the financial risks encountered in hospitals are evaluated according to the risk management approach.

Material and Methods: We used risk assessment tables for identifying the financial activities of healthcare organizations, L-type decision matrix for risk assessment, and financial risk ratio methods for enterprise performance indication. In compliance with the enterprise risk management guidelines, we collected qualitative data through an interview with the risk manager of a hospital and quantitative data was created and adapted by the authors.

Results: According to the study sample, among the risks identified in the procurement process, the risk score of the risk 1 is 3 , the risk score of the risk 3 is 4 , and the risk score of risk number 4 is 2 points, and was found to be acceptable. The risk score for risk 2 is 10 points and was found to be remarkable. The financial risk ratio of the hospital is 0.10 .

Conclusion: In the financial risk assessment, the risks in the hospital's procurement activities were determined as occurrence of public loss (No. 1), failure to procure the need (No. 2) and late procurement of the need (No. 4), which are all assessed as controllable risks. No. 4 is noteworthy enough to be distinguished from the other risks. Calculated financial risk ratios showed there were no risks for corporate performance of the healthcare organization in fulfilling the short-run obligations through its liquid assets.
\end{abstract}

Keywords: Financial risk; risk assessment; risk management.

ÖZ

Amaç: Risk değerlendirme risk yönetim sürecinin önemli bir adımıdır. Bu çalışma sağlık kuruluşlarında kurumsal risk yönetiminin önemini vurgulamak ve finansal faaliyetlere ait risklerin nasıl değerlendirilmesi gerektiğini bir örnekle göstermeyi amaçlamaktadır.

Gereç ve Yöntemler: Sağlık kuruluşlarının finansal faaliyetlerinin tanımlanmasında risk değerlendirme tablosu, risklerinin değerlendirilmesinde L tipi karar matrisi ve kurumsal performans göstergesi olarak finansal risk oranı yöntemi kullanılmıştır. Çalışmada kurumsal risk yönetimi yönergelerine göre finansal faaliyetlerin risk değerlendirmesi için gerekli olan nitel veriler bir hastanenin risk yöneticisinden görüşme yöntemiyle elde edilmiş, nicel veriler ise yazarlar tarafindan türetilerek örnek oluşturacak biçimde uyarlanmıştır.

Bulgular: Çalışmada tedarik süreci ile ilgili tanımlanan risklerden 1 nolu riske ait risk puanı 3, 3 nolu riskin risk puanı 4 ve 4 nolu riskin risk puan 2 puan olarak kabul edilebilir düzeyde bulunmuştur. 2 nolu riske ait risk puan 10 puan olarak dikkate değer bulunmuştur. Hastanenin finansal risk oranı ise 0,10 'dur.

Sonuç: Hastanenin tedarik faaliyetlerinin finansal risk değerlendirmesine göre, 1 nolu kamu zararı oluşması riski, 2 nolu ihtiyaca uygun mal alınamaması riski, 4 nolu ihtiyacın geç tedarik edilmesi riski kontrol edilebilir riskler olarak değerlendirilmiştir. 4 nolu ihtiyacın tedarik edilememesi riski ise dikkat edilmesi gereken risk olarak değerlendirilerek diğer risklerden ayrışmış̧ır. Ayrıca hesaplanan finansal risk oranına göre sağlık kuruluşunun kurumsal performansı finansal açıdan likit varlıkları ile kısa vadeli yükümlülüklerini karşılama riskinin bulunmadığı şeklinde değerlendirilmiştir.

Received / Geliş Tarihi : 15.01 Accepted / Kabul Tarihi : 23.03.2021 Available Online /

Çevrimiçi Yayın Tarihi : 25.03.2021
Anahtar kelimeler: Finansal risk; risk değerlendirme; risk yönetimi. 


\section{INTRODUCTION}

Healthcare quality is an indicator of the level of development. Healthcare facilities are important organizations in social and economic life (1). As a service enterprise, a healthcare organization is to produce health services for public needs through a combination of production factors (2). However, they are regarded as a different sector due to social importance of the service, market size and their own hallmarks (3).

As for risk management in healthcare organizations, in the heart of risk is patient and employee safety. Healthcare organizations are commercial enterprises and their financial, strategic and operational processes must be kept under control (4).

In Turkey, risk management in healthcare organizations focuses rather on patient and employee safety than such holistic approaches as Enterprise Risk Management (ERM) and risk-oriented management, internal control and audit, overlooking the emergence of risks in neglected areas of activities. The emergence of overlooked or neglected risks may lead to adverse outcomes including injuries and deaths in healthcare organizations. Such outcomes damage to patients, employees and third parties will affect the organization's financial structure as well (5). Risk management activities are of prime importance in operating financial activities and sustainability since the financial dimension of risk will affect the enterprise's financial activities.

Risk management in financial activities of healthcare organizations is assessed in two categories: Risks stemming from business processes and risks due to the organization's entire activities. In Turkey, risks in the financial activities of healthcare organizations are assessed according to the patient and employee criteria within quality management (6). The financial dimension of risks in operating activities is evaluated by the institutional performance and productivity assessment criteria (7). The importance of risk management is more connected with risks' financial outcomes than risk-related health and safety problems.

As in the ERM approach, holistic risk management applications may seem insufficient in healthcare organizations. Many healthcare organizations implement risk management strategies in programs, projects and services for clinical and patient safety. However, they are unsuccessful in enterprise risk management practices for financial success and sustainability (8-12).

The ERM approach is recommendable for improving the process of value creation and establishing a safer environment in healthcare organizations (13). In the articles on the application of ERM in healthcare organizations, while International Organization for Standardization (ISO) 31000 (14) and The Committee of Sponsoring Organizations of the Treadway Commission (COSO) (15) define the mutual steps of ERM as identification, analysis, assessment, monitoring and control, in the financial risk management studies on healthcare organizations, they are discussed by financial statement analysis, financial failure, bankruptcy prediction and institutional performance. No studies have discussed financial assessment of the risks that may occur in the operating process of healthcare organizations (16) and asserted risk management practices may improve their financial situations $(17-19,20)$.
The present study aims to emphasize the importance of enterprise risk management in healthcare organizations and demonstrate how to assess the risks in financial activities. In this context, risk management practices in healthcare organizations will be mentioned, risk assessment, which is one of the stages of risk management; it will be shown over the hospital sample using the risk assessment table, the L-type decision matrix, financial risk ratio methods, and will be evaluated.

\section{MATERIALS AND METHODS}

We used risk assessment tables $(5,8,18)$ for identifying the financial activities of healthcare organizations, L-type decision matrix $(8,19)$ for risk assessment, and financial risk ratio methods (7) for enterprise performance indication.

Neither risk assessment table nor decision matrix is the first step in risk management. First, risk management committee and unit managers need to fill in a risk assessment form that will detect, identify and assess the relevant business risks. Second, the collected information will be conveyed into a risk assessment matrix for a visual expression. L-type $5 \times 5$ matrix diagram is used for the assessment of cause and effect or probability and impact relation. This matrix is optimal for simple risk analysis. However, this method is insufficient for multi process works with various flow charts and its success rate may vary depending on the analyst's experiences (19).

In compliance with the enterprise internal audit guidelines, we collected qualitative data through an interview with the risk manager of a hospital and quantitative data was created and adapted by the authors.

Procurement services in hospitals are provided by the purchasing unit. The purchasing units are affiliated with the administrative and financial affairs directorate. Purchasing transactions in hospitals are conducted by the provisions of Public Procurement Law No. 4734 and Public Procurement Contracts Law No. 4735. This Law allows enterprises to satisfy their urgent needs on the condition that the cost cannot exceed $10 \%$ of the budget in accordance with Article 22/d (Direct procurement) (9). The purpose of direct procurement process is to supply reasonably priced quality needs at market price level.

The work flow of the direct procurement process, the identified risks, the causes of the risks and the responses to the risks are arranged in Table A1, Table A2 and Table A3 in the appendix of article.

\section{RESULTS}

The following tables include the probability value ranges (Table 1) and impact value ranges (Table 2) of financial activities used in the calculation of the risk score. The risk score is calculated according to the following formula:

\section{Risk score $=$ Probability value $x$ Impact value}

The risk definitions and probability and impact values of the direct procurement method are shown in Table A1 and Table A2 in the annex. According to these values, the risk scores are calculated and the following decision matrix tables shown (Table 3).

The interpretation of the risk scores in the decision matrix tables is shown in risk assessment table (Table 4). 
Table 1. Probability values

\begin{tabular}{lcc}
\hline \multicolumn{1}{c}{ Frequency } & Probability & Value \\
\hline At least once a year & Very low & 1 \\
At least once in every six months & Low & 2 \\
At least once in every three years & Medium & 3 \\
At least once a month & High & 4 \\
At least once a week & Very high & 5 \\
\hline
\end{tabular}

Table 3. Risk decision matrix

\begin{tabular}{|c|c|c|c|c|c|c|}
\hline \multirow{6}{*}{ 㝵 } & 5 & 5 & 10 & 15 & 20 & 25 \\
\hline & 4 & 4 & 8 & 12 & 16 & 20 \\
\hline & 3 & 3 & 6 & 9 & 12 & 15 \\
\hline & 2 & $\underline{\mathbf{2}}$ & $\underline{4}$ & 6 & 8 & $\underline{10}$ \\
\hline & 1 & 1 & 2 & $\underline{3}$ & 4 & 5 \\
\hline & & 1 & 2 & 3 & 4 & 5 \\
\hline
\end{tabular}

Table 2. Impact values

\begin{tabular}{lcc}
\hline \multicolumn{1}{c}{ Event } & Severity & Value \\
\hline Delay/Lag & Very low & 1 \\
High Cost & Low & 2 \\
Public Loss & Medium & 3 \\
Financial Distress & High & 4 \\
Termination of Activity & Very high & 5 \\
\hline
\end{tabular}

Low risk-green (1-6): Quick and simple precautions are applied immediately and additional measures are taken to the extent permitted by resources.

Moderate risk-yellow (7-14): Actions are performed as soon as possible but not after more than one year.

Excessive risk-red (15-25): Rapid actions are required. Risk committee/commission is given a briefing and remedial measures are taken immediately (10).

Table 4. Risk assessment

\begin{tabular}{ccccc}
\hline Risk No & Risk Score & Assessment & Frequency & Activity \\
\hline & & Unacceptable & Weekly & Urgent precautions are necessary \\
$\mathbf{2}$ & $\mathbf{1 0}$ & Notable & Monthly & Treatment is required \\
$\mathbf{1 - 3 - 4}$ & $\mathbf{3 - 4 - 2}$ & Acceptable & Semiannual & Must be monitored and counted in action plan \\
\hline
\end{tabular}

Enterprise financial performance evaluations of healthcare organizations are made by calculating financial risk ratios (Table 5). Accordingly, the following is an example of calculating the financial risk ratio of a healthcare organization. Example:

1 million TRY net debt (A), 10 million TRY average accrued amount (D), 500 thousand TRY unbillable service accruement amount (E), 10 million TRY aggregate collection amount (B) and 9.5 million TRY aggregate accruement (C).

$\mathrm{F}=\mathrm{A} /(\mathrm{D}+\mathrm{E}) \times(\mathrm{B} / \mathrm{C}) \quad \mathrm{F}=1,2$ million $/(10$ million +500 thousand $) \times 100$ million $/ 105$ million $\quad \mathrm{F}=0,11 \times 0,95 \quad \mathrm{~F}=0,10$

Table 5. Financial risk ratio (7)

\begin{tabular}{|c|c|c|c|c|c|}
\hline Indicator & Formula & Parameter & Target & $\begin{array}{c}\text { Average of } \\
\text { Relevant } \\
\text { Periods }\end{array}$ & 2020 \\
\hline Financial Risk Ratio & $\mathrm{F}=[\mathrm{A} /(\mathrm{D}+\mathrm{E})] *(\mathrm{~B} / \mathrm{C})$ & $\begin{array}{c}\text { A: Net Debt } \\
\text { B: Aggregate Collection } \\
\text { C: Aggregate Accruement } \\
\text { D: Average Accruement } \\
\text { E: Unbillable Service Accruement } \\
\text { F: Financial Risk Ratio }\end{array}$ & $\leq 2$ & & 0,10 \\
\hline
\end{tabular}

\section{DISCUSSION}

Risk scores according to the risk table method of the direct procurement method and the procurement process are provided in Table 6.

According to the risk assessment results; the risk scores of the risks of public loss and the inability to purchase goods for the needs are low because their impact values are high

Table 6. Ranking of risk scores

\begin{tabular}{cc}
\hline Risk ID & Risk Score \\
\hline 2 & 10 \\
3 & 4 \\
1 & 3 \\
4 & 2 \\
\hline
\end{tabular}

while their probability values are low. These risks are considered controllable risks according to the risk matrix. The impact value and probability value of the risk of not supply the requirement are higher than other risks. According to the risk matrix, this risk is considered a remarkable risk.

In order not to cause mistakes and negligence in not purchasing goods that meet needs, procurement professionals take a high level of care in procurements with high risk such as public damage. Therefore, the risk probability in hospitals is low. However, considering the external environmental factors, the risk probability of late supply and failure to supply is higher than other risks.

In this case, the late supply of the need is considered controllable and the failure to supply the need is considered remarkable. 
The stock tracking system performed by the Ministry of Health ensures control of the critical stock level in hospitals. This system reduces the risk possibility that may be encountered in the procurement process.

The financial processes risk in hospitals affect their financial performance. The financial risk ratio of the hospital is 0.10 . Enterprise has difficulties in discharging its debts over liquid assets when the financial risk ratio is greater than 2. Enterprise suffers from no difficulties if the ratio is equal to 2 or smaller than 2 (11). In public hospitals, high but unconvincing service costs lead to low revenue despite high sales volume. Public hospitals often suffer from resource insufficiency. The financial risk ratio (0.10), indicates that hospital does not have the risk to meet its liquid assets and current liabilities.

The study shows that risk assessment results of financial processes are consistent with financial performance risk values. This supports studies suggesting that risk management practices lead to improvements in the financial situation of healthcare institutions.

\section{CONCLUSION}

Hospitals must develop administrative activities for predicting potential risks and turning them into an opportunity to minimize possible losses. Hospitals with actively operating risk management will remain farther ahead of the game than those with no attempts to assure patient and employee safety and service quality. Potential risks and effects of these risks may vary depending on conditions, resources and environmental factors. Risk management is a proactive methodology for hospitals in fighting operational, clinical and financial risks. However, the variety and assessment of risks are challenging. Selfrecognition is highly important for enterprises.

Financial risk is usually associated with the probability of monetary loss. Financial risk is commonly defined as the probability for company to remain incapable of fulfilling its cash flow obligations. As in any other enterprises, financial risk is analyzed in healthcare organizations. However, the results of such an analysis may misdirect information users since financial reports are manipulated easily in the organizations with no enterprise risk management practices and no risk-oriented internal auditing.

In the present study, we have discussed financial risk management for hospitals and presented an example of financial risk assessment at financial level. Risk assessment varies depending on enterprises, sectors and risk areas. However, there are some essentials in financial risk assessment that any enterprise is supposed to comply with. Specialists suggest implementing an effective internal control and audit structure in healthcare organizations for the establishment of a risk-based administration system instead of various risk and audit activities. In financial risk assessment, self-recognition and competence in taking necessary precautions to turn risks into opportunities are of prime importance for enterprises. We have used basic methods of analysis and documents in this paper though there are numerous other methods and documents being used in financial risk assessment. We used risk assessment tables $(5,8,18)$ for identifying the financial activities of healthcare organizations, L-type decision matrix $(8,19)$ for risk assessment, and financial risk ratio methods (7) for enterprise performance indication.

However, such risk assessment practices will provide very low chance to diminish financial risks and contribute to financial structure in healthcare organizations with no internal audit mechanism that can transform the risk management process into a proactive system through an ERM-like holistic risk assessment approach. All in all, risk management activities are to increase enterprise value and assure sustainability. Thus, enterprise risk management must be put into practice and an internal auditing unit must be established for monitoring the risks regularly and updating the audit reports. Furthermore, risk assessment of healthcare organizations must be conducted by independent audit institutions and high risk organizations must receive compulsory risk management support.

The present study will guide risk managers of healthcare organizations in assessing the risks of their financial activities and contribute to the formation of an enterprise risk culture.

Ethics Committee Approval: Since our study was not an experimental study including human or animal subject, ethics committee approval was not required.

Conflict of Interest: None declared by the authors.

Financial Disclosure: None declared by the authors.

Acknowledgements: None declared by the authors.

Author Contributions: Idea/Concept: MT, IE; Design: MT, İE; Data Collection/Processing: MT, $\dot{\mathrm{I} E}$; Analysis/Interpretation: MT, İE; Literature Review: MT, İE; Drafting/Writing: MT, İE; Critical Review: MT, İE.

\section{REFERENCES}

1. Kubar Y. Relationship between economic growth and development indicators of less developed and developing countries: a panel data analysis (19952010). Ardahan University J. Faculty of Economics and Administrative Sciences. 2016;(4):65-99.

2. Türk M, Ertaş FC. Fuzzy time driven activity based costing system: an implementation in a hospital. Journal of Accounting and Taxation Studies. 2018;11(Special Issue):272-97.

3. Türk M, Çil Kocyigit S. Risk assessment process in hospitals. In: Aslan Ü, Bozkus Kahyaoglu S, editors. Selected topics in audit: internal audit internal control sectoral practices. 1th ed. Ankara: Gazi Kitabevi; 2020. p.69-86.

4. Özcan N. Risk management in health institutions. J Health Services and Education. 2018;2(1):15-24.

5. Ceylan H, Başhelvacı VS. Risk by risk assessment table method analysis: an application. International Journal of Engineering Research and Development. 2011;3(2):25-33.

6. Republic of Turkey Ministry of Health. Healthcare Quality Systems (SKS) - Hospital (Version 6). Ankara; Ministry of Health; 2020.

7. Republic of Turkey Ministry of Health. Efficiency OnSite Assessment Guide (Version 2019). Ankara; Ministry of Health; 2019. 
8. Aksoy T. An applied 3x5 risk analysis survey proposal for defining \& scoring of operational risks in riskbased internal audit process. Mali Çözüm. 2018;28(147):37-77.

9. Public Procurement Law No:4734.

10. Alam AY. Steps in the process of risk management in healthcare. J Epid Prev Med. 2016;2(2):13000118.

11. Akdoğan N, Tenker N. Financial statement analysis and financial analysis techniques. 13th ed. Ankara: Gazi Kitabevi; 2007.

12. American Society for Healthcare Risk Management (ASHRM). Enterprise risk management: A framework for success. 2014;6:53-73.

13. Etges APBDS, Grenon V, Lu M, Cardoso RB, de Souza JS, Kliemann Neto FJ, et al. Development of an enterprise risk inventory for healthcare. BMC Health Serv Res. 2018;18(1):578.

14. ISO. ISO 31000:2018 Risk management-Guidelines. 2018.

15. COSO. Enterprise risk management-Integrated framework. 2004.
16. WA Health Risk Management Policy and local risk management policy and related documents. Department of Health. 2019.

17. Fenn P, Egan T. Risk management in the NHS: governance, finance and clinical risk. Clin Med (Lond). 2012;12(1):25-8.

18. Public Internal Audit Guide. 2013.

19. Kantarcioglu H, Kantarcıoğlu A, Dinç H. Occupational health and safety in health institutions: An investigation on risk assessment methods in public hospitals. Health Care Acad J. 2020;7(1):61-7.

20. Tuten P. Building an ERM framework for valuefocused health care. [Cited: 2021, Feb 1]. Available from:

https://www.hfma.org/topics/hfm/2018/april/60218.ht $\mathrm{ml}$

21. Eaton G. Enterprise risk management \& the EMHS experience, 2017. [Cited: 2021, Feb 1]. Available from:

http://www.mainehfma.org/site/files/263/163409/539 537/775986/Enterprise_Risk_Management.pdf 


\section{The Appendix:}

Table A1. Risk determination form

\begin{tabular}{|c|c|c|c|c|c|}
\hline \multicolumn{5}{|c|}{ Management/Unit/Subunit: } & \multirow{2}{*}{ Date: ......./20.... } \\
\hline 1 & 2 & 3 & 4 & 5 & \\
\hline Order & $\begin{array}{c}\text { Reference } \\
\text { No }\end{array}$ & $\begin{array}{c}\text { Name of } \\
\text { Business } \\
\text { Process }\end{array}$ & Steps in Business Process & Risk Determined & Reason for Risk \\
\hline 1 & IMISB-1 & \multirow{4}{*}{ 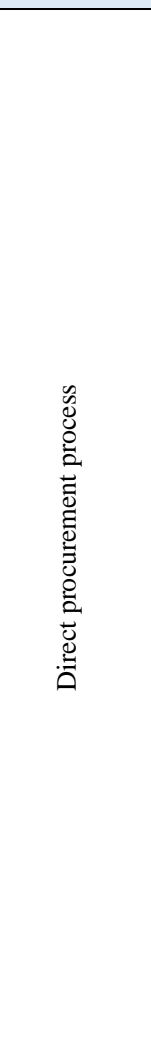 } & \multirow{4}{*}{$\begin{array}{l}\text { *Determination of the need } \\
\text { *Preparation of technical specification } \\
\text { *Purchasing unit's demand for procurement } \\
\text { *Budget control } \\
\text { *Approval of expenditure order if budget is } \\
\text { appropriate } \\
\text { *Approval of market price survey commission } \\
\text { *Conduction of a market survey } \\
\text { *Approval of pricing } \\
\text { *Approval of inspection and acceptance } \\
\text { commission } \\
\text { *Placing and order } \\
\text { *Acceptance or return of goods in accordance } \\
\text { with the Goods Inspection and Acceptance } \\
\text { Regulation } \\
\text { * Issuing a movable transaction bill } \\
\text { *Issuing a payment order } \\
\text { *Assessment officer's approval of payment } \\
\text { order } \\
\text { *Submitting payment order and documents } \\
\text { regarding additional expenditures to accounting } \\
\text { unit }\end{array}$} & Occurrence of public loss & $\begin{array}{l}\text { *Unnecessary, missing or too many demands } \\
\text { *Final price of the need exceeding its market price due to } \\
\text { defective market survey } \\
\text { *Payment before delivery } \\
\text { *Payment without the completion of pre-purchase inspection } \\
\text { and acceptance }\end{array}$ \\
\hline 2 & IMISB -2 & & & Failure to procure the need & $\begin{array}{l}\text { *Lack of allocation for the need in budget } \\
\text { *Lack of sufficient allocations in budget }\end{array}$ \\
\hline 3 & IMISB -3 & & & $\begin{array}{l}\text { Failure to purchase goods for the } \\
\text { need }\end{array}$ & $\begin{array}{l}\text { *Erroneous preparation of specification } \\
\text { *Commission's inappropriate buyouts } \\
\text { *Lack of actualized inspection and acceptance }\end{array}$ \\
\hline 4 & IMISB -4 & & & Late procurement of the need & $\begin{array}{l}\text { *Documents are prepared late } \\
\text { *Document preparation is missing or erroneous } \\
\text { *Time constraints } \\
\text { *Supplier's late delivery of goods } \\
\text { *Supplier's late delivery of documents } \\
\text { *Supplier's erroneous preparation of documents }\end{array}$ \\
\hline
\end{tabular}

Risk determination is a process when healthcare professionals and staff become aware of the risks in medical services. Determined risks are registered in risk determination form. 
Table A2. Risk voting form

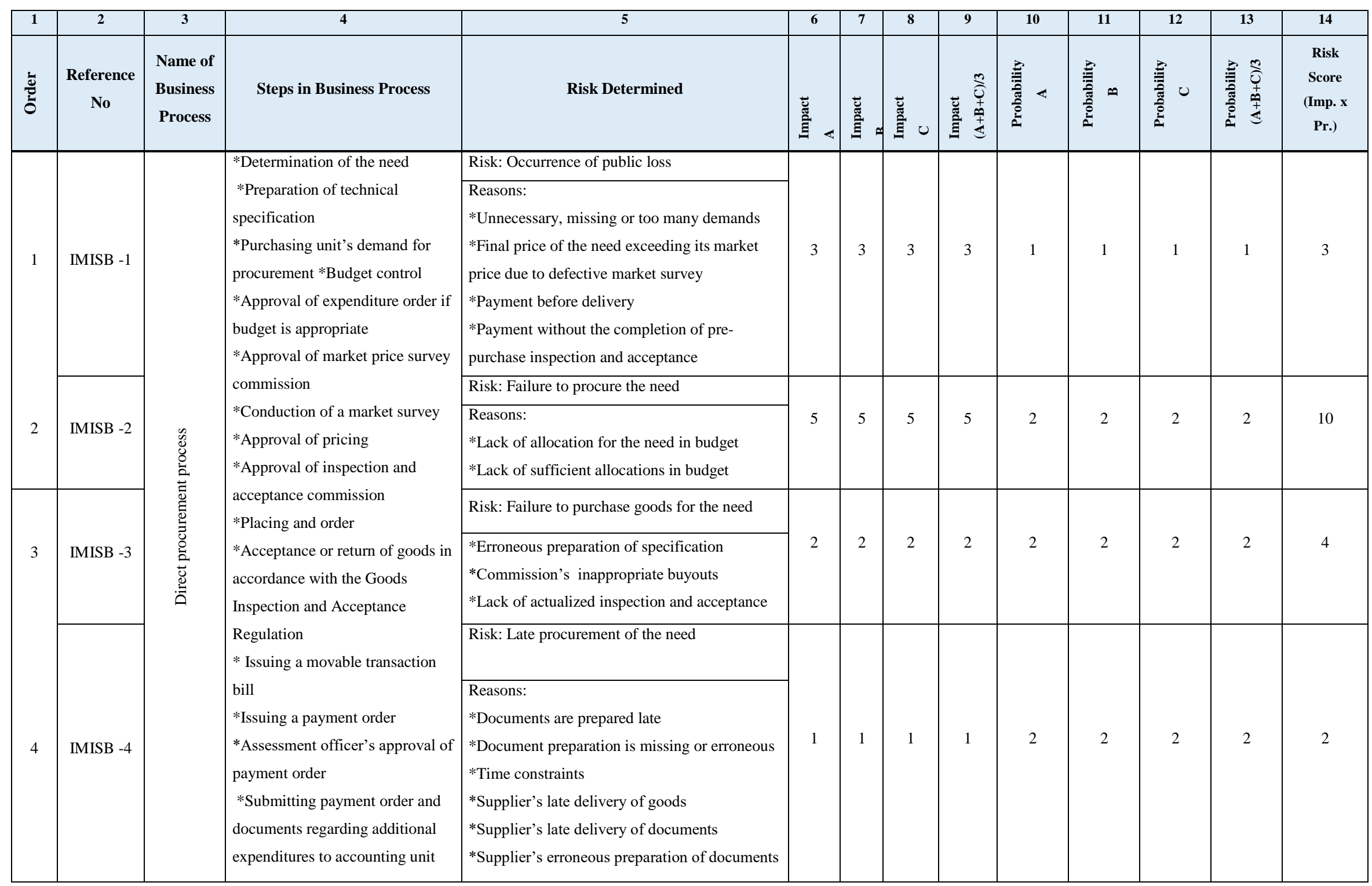

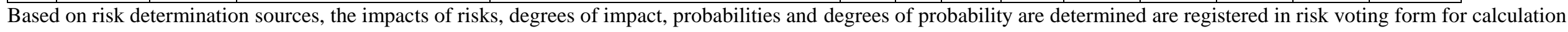
of risk scores. 
Table A3. Risk registration form

\begin{tabular}{|c|c|c|c|c|c|c|c|c|c|c|c|c|c|}
\hline \multicolumn{7}{|c|}{ Management/Unit/Subunit: } & \multicolumn{7}{|c|}{ Date: .../../20.... } \\
\hline 1 & 2 & 3 & 4 & 5 & 6 & 7 & 8 & 9 & 10 & 11 & 12 & 13 & 14 \\
\hline$\dot{\bar{g}}$ & $\begin{array}{c}\text { Reference } \\
\text { No }\end{array}$ & $\begin{array}{l}\text { Name of } \\
\text { Business } \\
\text { Process }\end{array}$ & $\begin{array}{l}\text { Steps in Business } \\
\text { Process }\end{array}$ & Risk Determined & Responses to Risk: Current Controls & 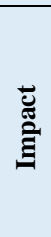 & 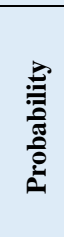 & $\begin{array}{c}\text { Risk } \\
\text { Score } \\
\text { (R) }\end{array}$ & \begin{tabular}{|c|} 
Change \\
(Direction \\
of Risk)
\end{tabular} & $\begin{array}{c}\text { Responses to } \\
\text { Risk: New/ } \\
\text { Additional/ } \\
\text { Removed } \\
\text { Controls }\end{array}$ & $\begin{array}{l}\text { Start } \\
\text { Date }\end{array}$ & $\begin{array}{c}\text { Risk } \\
\text { Holder }\end{array}$ & Statements \\
\hline 1 & IMISB -1 & 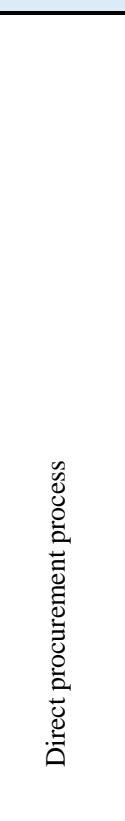 & $\begin{array}{l}\text { *Determination of the } \\
\text { need } \\
\text { *Preparation of technical } \\
\text { specification } \\
\text { *Purchasing unit's } \\
\text { demand for procurement } \\
\text { *Budget control } \\
\text { *Approval of expenditure } \\
\text { order if budget is } \\
\text { appropriate } \\
\text { *Approval of market price } \\
\text { survey commission } \\
\text { *Conduction of a market } \\
\text { survey } \\
\text { *Approval of pricing } \\
\text { *Approval of inspection } \\
\text { and acceptance }\end{array}$ & $\begin{array}{l}\text { Risk: Occurrence of public } \\
\text { loss } \\
\text { Reasons: } \\
\text { *Unnecessary, missing or too } \\
\text { many demands } \\
\text { *Final price of the need } \\
\text { exceeding its market price } \\
\text { due to defective market } \\
\text { survey } \\
\text { *Payment before delivery } \\
\text { *Payment without the } \\
\text { completion of pre-purchase } \\
\text { inspection and acceptance }\end{array}$ & $\begin{array}{l}\text { *Pricing out commission receives tender } \\
\text { from at least three companies } \\
* \text { Commission compares tendered prices } \\
\text { with those in the market } \\
\text { * Commission compares tendered prices } \\
\text { with costs of other similar tasks } \\
\text { determined by administration } \\
* \text { Procurement demand is made with } \\
\text { movable requisition } \\
\text { * Registration officer confirms storage } \\
\text { for the need and confirms movable } \\
\text { requisition } \\
* \text { Inspection and acceptance commission } \\
\text { accepts orders after enumerating, } \\
\text { weighing and/or measuring them } \\
* \text { Storehouse supervisors verify } \\
\text { information in the acceptance report }\end{array}$ & 3 & 1 & 3 & & & & $\begin{array}{c}\text { Director of } \\
\text { Financial } \\
\text { and Adm. } \\
\text { Services }\end{array}$ & \\
\hline 2 & IMISB -2 & & 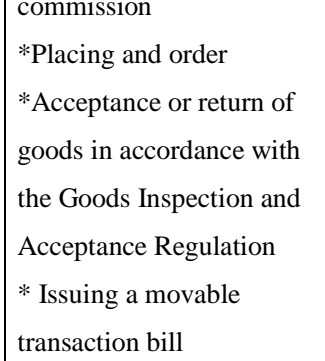 & \begin{tabular}{|l|} 
Risk: Failure to procure the \\
need \\
Reasons: \\
*Lack of allocation for the \\
need in budget \\
*Lack of sufficient \\
allocations in budget \\
\end{tabular} & $\begin{array}{l}* \text { The needs are determined precisely } \\
\text { according to annual plans and programs } \\
\text { *Reasoned payment offers are made } \\
\text { during budget preparation*Requesting for } \\
\text { allocation transfer for the allowances that } \\
\text { are not offered during budget } \\
\text { preparation* Supplying additional } \\
\text { allocation for insufficient allowances }\end{array}$ & 5 & 2 & 10 & & & & $\begin{array}{c}\text { Director of } \\
\text { Financial } \\
\text { and Adm. } \\
\text { Services }\end{array}$ & \\
\hline
\end{tabular}




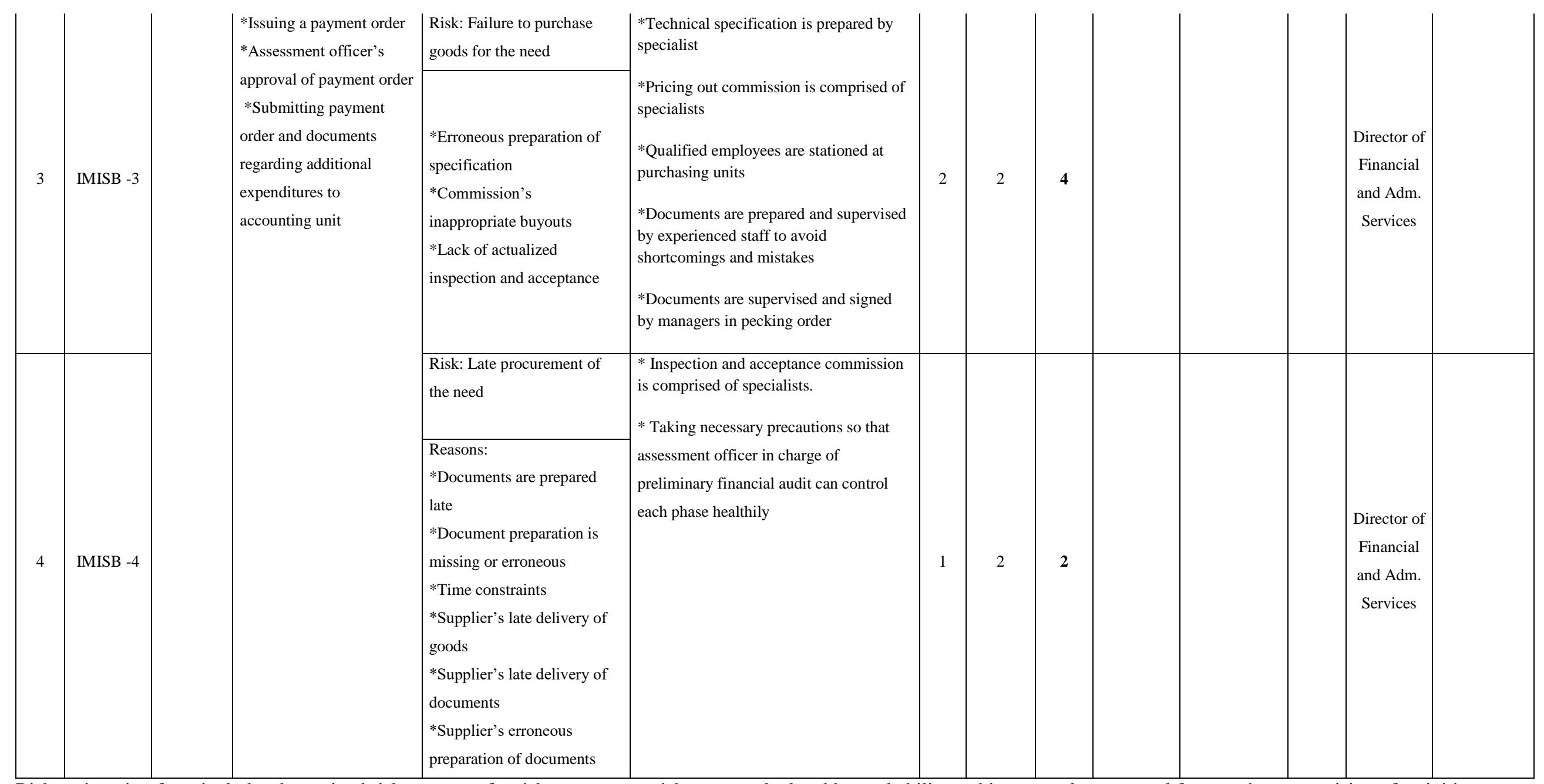

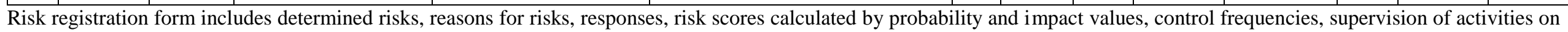
hand, management of such risks as change results, and other relevant terms. Risk data on all units is followed in consolidated risk registration form. 